УДК 159.9.07

DOI: https://doi.org/10.33120/ssj.vi46(49).165

\author{
Лазоренко Борис Петрович \\ кандидат філософських наук, старший науковий співробітник, \\ провідний науковий співробітник лабораторії \\ соціальної психології особистості, \\ Інститут соціальної та політичної психології НАПН України, \\ м. Київ, Україна \\ ORCID ID 0000-0002-2113-0424 \\ bolaz@ukr.net
}

\title{
НАВЧАЛЬНО-МЕТОДИЧНИЙ СУПРОВІД ОПАНУВАННЯ КУРСАНТАМИ-ПСИХОЛОГАМИ СТРЕСОВИХ СТАНІВ: ЗАСОБИ САМО- ТА ВЗАЕМОДОПОМОГИ
}

\begin{abstract}
Визначено основні чинники результативності навчально-методичного супроводу опанування стресових і посттравматичних стресових станів засобами само- і взаємодопомоги курсантами - військовими психологами першого курсу навчання і магістрантами. За авторською анкетою проведено порівняльний аналіз самооцінювання їхніх умінь та первинних навичок, а також здатності надавати психологічну допомогу в цьому особовому складі. Використано також методи включеного спостереження, індивідуального консультування, співбесіди з учасниками для отримання від них зворотного зв'язку. Як основні серед чинників результативності навчально-методичного супроводу визначено активність, мотивацію, спрямованість та командну згуртованість курсантів. Зясовано, що останній чинник у першокурсників проявився більшою мірою, ніж у магістрантів: першокурсники були більш зацікавленими в самопідготовці і дещо активнішими під час аудиторних занять. Хоч і магістранти, і першокурсники засвідчили, що отримали основні базові знання й уміння та зможуть самостійно їх застосовувати у своїй професійній діяльності, однак рівень засвоєння технологій у першокурсників загалом вищий, ніж у магістрантів. Встановлено, що курсанти оволоділи груповими техніками зняття стресових і посттравматичних стресових станів і зможуть скористатися ними під час проведення занять 3 особовим складом. Завдяки проведеному самооцінюванню з'ясовано, що вони засвоїли основні тілесно зорієнтовані та дихальні психотехнології зняття стресових і поттравматичних стресових станів у різних зонах тіла. При цьому показники першокурсників за всіма позиціями дещо вищі, ніж у магістрантів. Разом з тим кожен четвертий із числа курсантівмагістрантів засвідчив, що не отримав необхідних знань та умінь і не зможе самостійно застосовувати запропоновані технології у своїй професійній діяльності. Ще майже кожен третій магістрант зазначив, що запропоновані технології видалися йому малоефективними. Аналіз анкетних відповідей цих учасників показав, що вони набули певних знань та умінь, проте потребують більше пояснень, додаткових знань та вмінь і тренінгових вправ для посилення впевненості у собі та власних фахових компетенціях. На відміну від магістрантів, у всіх першокурсників оцінки засвоєння та ефективності цих технологій були позитивними. Встановлено, що понад половину учасників занять мають потребу в отриманні додаткових знань та умінь щодо застосування запропонованих технологій. Також з'ясовано, що участь у спецкурсі стала стимулом для вдосконалення фахової психологічної підготовки його учасників. 3'ясовано, що у першокурсників ця потреба $є$ більш вираженою, ніж у магістрів. Фактична здатність ефективно застосовувати набуті учасниками знання та вміння може бути визначена лише під час їхньої практичної діяльності, тому результативність навчальнометодичного супроводу потребує дослідження під час стажування у військах та під час практичної роботи з особовим складом за місцем проходження служби.

Ключові слова: навчально-методичний супровід; курсанти - військові психологи; посттравматичні стресові стани; тілесні психотехнології; дихальні психотехнології.
\end{abstract}




\title{
EDUCATIONAL-METHODICAL SUPPORT OF CADETS- PSYCHOLOGISTS' STRESS STATES MANAGEMENT: MEANS OF SELF- AND MUTUAL ASSISTANCE
}

\author{
Borys P. Lazorenko \\ Ph.D. in Philosophy, Senior Researcher, Leading Research Associate, \\ Laboratory of Social Psychology of Personality, \\ Institute for Social and Political Psychology, NAES of Ukraine, \\ Kyiv, Ukraine \\ ORCID ID 0000-0002-2113-0424 \\ bolaz@ukr.net
}

There are determined the main factors of effectiveness of educational-methodical support in overcoming stressful and post-traumatic stressful states by means of self- and mutual assistance by cadets - military psychologists of the first year of study and undergraduates. According to the author's questionnaire, it is made a comparative analysis of self-assessment of their skills and primary abilities, as well as the ability to provide psychological assistance to such personnel. Methods of included observation, individual counseling, interviews with participants were also used to get feedback from the participants. The main factors of effectiveness of educational-methodical support are determined the activity, motivation, orientation, and team cohesion of cadets. It was found that the last factor was more pronounced in first-year students than in undergraduates: freshers were more interested in self-preparation and somewhat more active during classroom studies. Although both undergraduates and first-year students have demonstrated that they have acquired basic knowledge and skills and will be able to apply them independently in their professional activities, the level of technology acquisition in freshers is generally higher than in undergraduates. It is established that the cadets have mastered group techniques for relieving stress and post-traumatic stress and will be able to use them during classes with personnel. The self-assessment revealed that they have mastered the basic body-oriented and breathing psychotechnologies for relieving stress and post-traumatic stress in different areas of the body. At the same time, the indicators of first-year students in all positions are slightly higher than those of undergraduates. It is noted that every fourth of the undergraduate cadets testified that he did not receive the necessary knowledge and skills and will not be able to apply the proposed technologies in their professional activities. Almost every third undergraduate noted that the proposed technologies seemed to him ineffective. The analysis of the questionnaire responses of these participants showed that they have acquired certain knowledge and skills, but need more explanations, additional knowledge, and training exercises to strengthen selfconfidence and their own professional competencies. In contrast to undergraduates, all first-year cadets had positive assessments of the mastery and effectiveness of these technologies. It is established that more than half of the participants need additional knowledge and skills in the application of the proposed technologies. It was also found that participation in the special course was an incentive to improve the professional psychological training of its participants. It was found that this need is more pronounced in first-year cadets than in undergraduates. The actual ability to effectively apply the knowledge and skills acquired by participants can be determined only during their practical activities, so the effectiveness of training needs research during training in the military activities and during practical work with personnel at the place of service.

Keywords: educational-methodical support; cadets-military psychologists; post-traumatic stress' states; body psychotechnology; breathing psychotechnology.

Постановка проблеми. Оволодіння вміннями само- і взаємодопомоги для опанування стресових і посттравматичних станів $€$ важливою складовою підготовки курсантів до виконання своїх обов'язків як військових психологів. Для українських військових психологів це завдання значною мірою актуалізується в умовах тривання воєнних дій на сході України та стану гібридності миру в країні. Також зазначені вміння є значущими, коли йдеться про надання особовому складу першої психологічної допомоги в опануванні стресових станів. 
Аналіз останніх досліджень і публікацій, виокремлення нерозв'язаних частин загальної проблеми. Зважаючи на зростаючу потребу у формуванні знань, умінь i первинних навичок у майбутніх військових психологів, численні роботи зарубіжних i вітчизняних авторів присвячено дослідженню цієї теми та розробленню відповідних навчальних курсів. Зокрема, зарубіжні дослідники значущу увагу приділяють ефективності сучасних навчальних методів стрес-тренінгу і погодженню методів підготовки керівного та особового складу військовослужбовців із новими вимогами їхньої діяльності в непередбачуваних і неоднозначних гострих стресових ситуаціях (Gallard, Soeters, \&, 2006). У дослідженнях російських психологів велике місце відводиться аналізу функцій військового психолога, зокрема його підготовці до роботи з особовим складом у кризових ситуаціях та стресових станах, забезпеченню військовослужбовців відповідним психологічним супроводом (Волкова, 2016). Вітчизняні дослідники вивчають особливості опанування курсантами психологами знань та умінь роботи 3 кризовими станами та конфліктними ситуаціями (Балашова, Васильєв, \& Дубровинський, 2013), особливості психологічної роботи 3 військовослужбовцями на етапі відновлення (Осьодло, \& Зубовський, 2017), посттравматичне зростання особистості учасників бойових дій (Кокун, Агаєв, Пішко, Лозінська, \& Остапчук, 2017). Найбільш популярні технології опанування стресових і посттравматичних стресових станів використовують зазвичай напрацювання когнітивноповедінкової терапії, арттерапії, ДПДГ-терапії. Значно менша увага звертається на тілесно зорієнтовані і дихальні технології, які, на наше переконання, мають значний потенціал оптимізації, коли йдеться про зняття посттравматичних стресових станів та їх профілактику.

Метою статті $\epsilon$ порівняльний аналіз самооцінки курсантами - військовими психологами першого курсу навчання і магістрантами досягнутих умінь та первинних навичок само- і взаємодопомоги в опануванні ними стресових і посттравматичних стресових станів, а також їхньої здатності надавати психологічну допомогу особовому складу за місцем проходження служби.

Виклад основного матеріалу дослідження. Для опанування курсантамипсихологами тілесно зорієнтованих і дихальних технологій само- і взаємодопомоги та їх використання в роботі з особовим складом нами було розроблено методику супроводу військового психолога, яка б допомогла йому набути відповідні знання, уміння, навички і практики. Методика передбачає проведення для курсантів-психологів першого курсу та магістрантів відповідних занять з цієї тематики, а також закріплення і корекцію набутого ними досвіду застосування набутих знань та умінь під час стажування у військах та в практичній роботі з особовим складом за місцем проходження служби. Розроблено також відповідний спецкурс. Проведення спецкурсу підтримали керівництво та фахівці Київського національного університету імені Тараса Шевченка, зокрема начальник кафедри військової психології та педагогіки Військового інституту полковник Н. Мась і доцент кафедри соціальної психології Г. Дубровинський. Допомогу в проведенні практичних занять надав студент-психолог Інституту підготовки кадрів Державної служби зайнятості України О. Ейгельсон. Спецкурс обсягом 6 занять проводиться по 2 академічні години один раз на тиждень протягом півтора-двох місяців. Його пройшли курсанти-магістранти Військового інституту Київського національного університету імені Тараса Шевченка (навесні 2019 року,) і курсанти-психологи першого курсу цього ж закладу освіти (восени 2019 року).

Зміст спецкурсу складали групові та індивідуальні психотехнології визначення й усунення основних тілесних блоків напруження як наслідків стресових і посттравматичних стресових станів, а також психотехнології командотворення. Соціально-психологічні технології відновлення особистості після травматичних подій, зокрема психотехнології самоі взаємодопомоги, більш грунтовно розкрито в практичному посібнику, підготовленому лабораторією соціальної психології особистості ІСПП НАПН України (Титаренко та ін., 2019), а технології командотворення - у попередній авторській публікації (Лазоренко, \& Дубровинський, 2019). Набуттю умінь та навичок 3 оволодіння зазначеними 
психотехнологіями були присвячені командні та парні тренінгові заняття, завдання із самопідготовки виконувались у перервах між аудиторними навчальними заняттями.

Серед завдань, які ставилися перед учасниками спецкурсу, основними були набуття знань, умінь і формування первинних навичок само- та взаємодопомоги в ситуаціях переживання особою стресових і посттравматичних стресових станів, зокрема надання психологічної допомоги в цьому особовому складі.

Під час проведення дослідження ми скористались авторською анкетою самооцінювання отриманих результатів, включеним спостереженням, індивідуальним консультуванням, співбесідами 3 учасниками та отриманим від них зворотним зв'язком. Анкетування учасників проводилось анонімно. Респонденти вказували стать і вік, а також досвід участі в бойових діях та стажування у військах, досвід навчання у військовому ліцеї. Спостереження за формуванням умінь відбувалося під час проведення занять. Відповіді на запитання, зворотний зв'язок, індивідуальне консультування та співбесіди проводилися по закінченні основних занять.

Загалом у дослідженні взяли участь 42 респонденти - 24 курсанти-психологи магістерського курсу і 18 першокурсників. Серед магістрантів було 16 чоловіків (віком від 21 до 26 років) і 8 жінок (віком від 19 років до 28 років), 2 особи мали статус учасника бойових дій, 7 осіб - досвід стажування у військах. У групі курсантів-психологів першого року навчання, які взяли участь у дослідженні, було 12 чоловіків, (11 юнаків віком від 17 до 19 років та один курсант 30 років), і 6 дівчат (віком від 16 доі 18 років); 3 особи мали досвід навчання у військовому ліцеї, 1 особа - 10 років стажу військової служби. Анкетування респондентів проводилося на заключному занятті.

Перш за все учасникам спецкурсу було запропоновано здійснити самооцінювання активності за двома питаннями (табл. 1).

Таблиия 1

Показники самооцінки активності участі в спецкурсі курсантів-психологів (магістрантів і першокурсників)

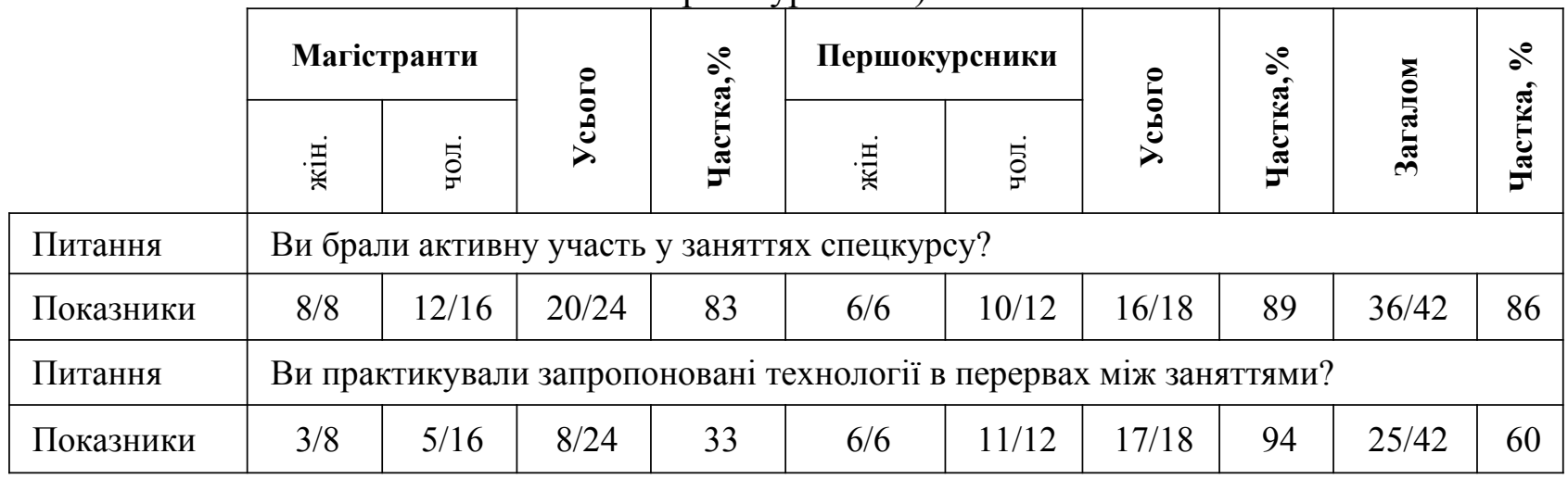

Відповіді учасників свідчать про те, що і магістранти, і першокурсники брали активну участь в аудиторних заняттях, проте першокурсники значно більше практикували під час самопідготовки, ніж магістранти (94\% і 33\%, відповідно), що в кінцевому підсумку позначилося на отриманих ними результатах.

Ми проаналізували також результати самооцінювання майбутніми військовими психологами засвоєння ними тілесно зорієнтованих і дихальних психотехнологій зняття поттравматичних стресових станів у різних зонах тіла (табл. 2). Курсанти засвідчили рівень своїх умінь визначати і знімати стресове напруження в зазначених зонах тіла. При цьому учасники набули вміня знімати стресові стани більшою мірою в зонах голови, шиї, плечей i тулуба і дещо меншою - у зонах серця і тулуба. 
Показники самооцінки засвоєння курсантами тілесно зорієнтованих і дихальних психотехнологій зняття посттравматичних стресових станів у різних зонах тіла

\begin{tabular}{|c|c|c|c|c|c|c|c|c|c|c|}
\hline \multirow{2}{*}{$\begin{array}{c}\text { Зони } \\
\text { стресового } \\
\text { напруження }\end{array}$} & \multicolumn{2}{|c|}{ Магістранти } & \multirow{2}{*}{$\begin{array}{l}0 \\
\dot{0} \\
\dot{0}\end{array}$} & \multirow{2}{*}{ 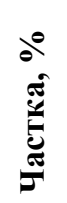 } & \multicolumn{2}{|c|}{ Першокурсники } & \multirow{2}{*}{ 苛 } & \multirow{2}{*}{ 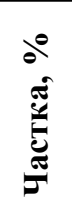 } & \multirow{2}{*}{ } & \multirow{2}{*}{ 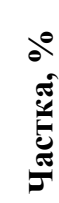 } \\
\hline & 安 & 官 & & & . & 官 & & & & \\
\hline $\begin{array}{l}\text { голови, } \\
\text { шиї } \\
\text { і плечей }\end{array}$ & $7 / 8$ & $12 / 16$ & $19 / 24$ & 79 & $4 / 6$ & $12 / 12$ & $16 / 18$ & 89 & $35 / 42$ & 83 \\
\hline серця & $4 / 8$ & $9 / 16$ & $13 / 24$ & 54 & $3 / 6$ & $9 / 12$ & $12 / 18$ & 67 & $25 / 42$ & 60 \\
\hline тулуба & $5 / 8$ & $7 / 16$ & $12 / 24$ & 50 & $4 / 6$ & $10 / 12$ & $14 / 18$ & 78 & $26 / 42$ & 62 \\
\hline
\end{tabular}

При цьому більшість магістрантів (75\%) і всі першокурсники зазначили, що отримали базові знання та вміння і зможуть самостійно застосовувати технології спецкурсу у своїй професійній діяльності. Також значна частина учасників (33\% магістрантів і $77 \%$ першокурсників) відчули потребу в подальшому вдосконаленні своєї фахової психологічної підготовки (табл. 3).

Таблиця 3

Показники самооцінки основних результатів, досягнутих курсантами - військовими психологами

\begin{tabular}{|c|c|c|c|c|c|c|c|c|c|c|}
\hline & \multicolumn{2}{|c|}{ Магістранти } & \multirow[b]{2}{*}{ 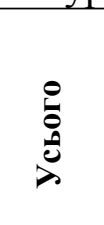 } & \multirow{2}{*}{\begin{tabular}{l}
$\partial^{0}$ \\
$\frac{\tilde{E}}{\tilde{E}}$ \\
$\frac{\tilde{E}}{\sigma}$ \\
\multirow{E}{*}{}
\end{tabular}} & \multicolumn{2}{|c|}{ Першокурсники } & \multirow[b]{2}{*}{$\begin{array}{l}\stackrel{\theta}{0} \\
\text { d. } \\
\text { è }\end{array}$} & \multirow{2}{*}{$\begin{array}{l}\partial^{0} \\
\tilde{E} \\
\frac{\tilde{E}}{5} \\
\frac{\tilde{E}}{\sigma}\end{array}$} & \multirow[b]{2}{*}{ 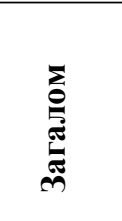 } & \multirow{2}{*}{ 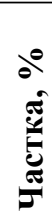 } \\
\hline & 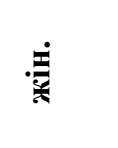 & $\dot{5}$ & & & 蒫 & ड் & & & & \\
\hline Питання & \multicolumn{10}{|c|}{$\begin{array}{l}\text { Чи вважаєте ви, що отримали первинні знання та уміння і зможете самостійно } \\
\text { застосовувати запропоновані технології у своїй професійній діяльності? }\end{array}$} \\
\hline Показники & $5 / 8$ & $13 / 16$ & $18 / 24$ & 75 & $6 / 6$ & $12 / 12$ & $18 / 18$ & 100 & $36 / 42$ & 86 \\
\hline Питання & \multicolumn{10}{|c|}{$\begin{array}{l}\text { Чи потребуєте ви додаткових знань та умінь щодо застосування запропонованих } \\
\text { технологій? }\end{array}$} \\
\hline Показники & $5 / 8$ & $9 / 16$ & $14 / 24$ & 58 & $5 / 6$ & $6 / 12$ & $11 / 18$ & 61 & $25 / 42$ & 60 \\
\hline Питання & \multicolumn{10}{|c|}{$\begin{array}{l}\text { Чи вважаєте ви, що технології, які пропонувались у навчальному спецкурсі, є для вас } \\
\text { малоефективними? }\end{array}$} \\
\hline Показники & $1 / 8$ & $6 / 16$ & $7 / 24$ & 29 & $0 / 6$ & $0 / 18$ & $0 / 24$ & 0 & $7 / 42$ & 17 \\
\hline Питання & \multicolumn{10}{|c|}{$\begin{array}{l}\text { Чи відчули ви завдяки участі в спецкурсі потребу у вдосконаленні своєї фахової } \\
\text { психологічної підготовки? }\end{array}$} \\
\hline Показники & $3 / 8$ & $5 / 16$ & $8 / 24$ & 33 & $6 / 6$ & $8 / 12$ & $14 / 18$ & 77 & $36 / 42$ & 86 \\
\hline
\end{tabular}

Важливим для нас $є$ аналіз анкет осіб, які вважають, що вони не отримали необхідні первинні знання та вміння і не зможуть самостійно застосовувати запропоновані технології у своїй професійній діяльності, і тих, хто вважає, що ці технології є для них малоефективними. Серед тих, хто зазначив, що не отримав належних умінь, було 6 осіб із числа магістрантів (25\% від їх чисельності); серед учасників, яким запропоновані технології видалися малоефективними, визначилося 7 осіб, теж із числа магістрантів (29\%, відповідно). Зазначимо, що 3 курсанти-магістранти обрали обидві негативні щодо спецкурсу відповіді. Натомість серед курсантів-першокурсників таких оцінок не було взагалі. 
Ми приділили відтак увагу аналізу відповідей курсантів-магістрантів, щоб з'ясувати можливі причини таких оцінок. Серед 6 осіб, які зазначили, що не отримали необхідних знань та умінь, було 3 жінки і 3 чоловіки.

Серед жінок одна учасниця написала, що потребує більше пояснень щиодо проведення пропонованих вправ і їхньої спрямованості та більше прикладів і ситуацій застосування тих чи інших вправ. Разом з тим вона зазначила, що все ж таки зможе скористатися основними запропонованими технологіями під час проведення групових занять. Також вона зауважила, що відкрила для себе нові технології самодопомоги. Друга жінка вказала, що потребує додаткових знань та умінь, хоча й була активна на заняттях і практикувала в перервах між заняттями. Вона зазначила, що в цілому зможе скористатись основними техніками під час проведення групових занять. Третя жінка (28 років), яка має досвід участі в бойових діях, на наш погляд, досягла дуже хороших результатів, однак має завищену вимогливість до власної фахової спроможності і рівня підготовки. Вона зазначила, що брала активну участь у заняттях, практикувала запропоновані технології в перервах між заняттями. Також відмітила, що набула умінь і зможе скористатись усіма техніками під час проведення групових занять 3 особовим складом та зможе визначити і “зняти” стресове напруження в основних зонах тіла. Оцінюючи корисність для себе участі в спецкурсі, жінка написала, що завдяки йому вона змогла "зрозуміти свою сутність і дійти згоди із самою собою". На наш погляд, ця жінка потребує додаткових тренінгових вправ, щоб набути більшої впевненості в собі і своїх професійних компетенціях.

Отже, аналіз самооцінки досягнутих результатів жінок-магістрантів показав, що загалом учасниці набули певних умінь, а одна із них досягла досить високих показників, проте вони потребують більше пояснень, додаткових знань та умінь і тренінгових вправ, які б сприяли посиленню впевненості в собі та власних фахових компетенціях.

Троє чоловіків-магістрантів, які вважають, що вони не отримали необхідні первинні знання та уміння і не зможуть самостійно застосовувати запропоновані технології у своїй професійній діяльності, усе ж визнали певний рівень оволодіння запропонованими технологіями. Так, один із магістрантів, серед іншого, зазначив, що зможе скористатись усіма техніками проведення групових занять з особовим складом, а також деякими техніками визначення і зняття стресових станів, проте має потребу в оволодінні технологіями вирішення внутрішньоособистісного конфлікту - і як технологіями самодопомоги, і як технологіями допомоги особовому складу. Також він зазначив, що потребує додаткових знань та вмінь щзодо застосування технологій. Цей курсант, на наш погляд, потребував більшої індивідуальної уваги та допомоги в засвоєнні навчального матеріалу для отримання більшої користі для себе від участі в спецкурсі. Другий магістрант зазначив, що зможе скористатися деякими техніками проведення групових занять з особовим складом, визначити і зняти стресові напруження в деяких зонах тіла. Проте він не потребує додаткових знань та умінь щодо застосування запропонованих технологій. Натомість у побажаннях щодо вдосконалення курсу він висловив низку критичних зауважень, що стосувалися покращення зворотного зв'язку і зацікавленості курсантів у цьому спецкурсі. На наш погляд, цей курсант також потребував особливої уваги та індивідуального підходу в опрацюванні основних завдань спецкурсу. Нашу увагу привернув третій курсант-магістрант, який практично на всі питання дав негативні відповіді. І хоч він зазначив, що брав активну участь у заняттях, проте висловив переконаність, що не потребує додаткових знань та умінь і не відчуває потреби у вдосконаленні своєї фахової психологічної підготовки. Припускаємо, що цей курсант проявив певний спротив до засвоєння матеріалу спецкурсу як ретравматичного і потребує відтак індивідуального підходу щодо опрацювання завдань.

Отже, і чоловіки-магістранти, крім останнього учасника, які зазначили, що не отримали очікуваних результатів, усе ж набули базових умінь опрацювання стресових i посттравматичних стресових станів. Однак вони потребували більше уваги, індивідуального підходу щодо виконання основних завдань, пояснень та допомоги в засвоєнні навчального матеріалу. 
На жаль, майже третина (29\%) магістрів (одна жінка і шість чоловіків) зазначили, що запропоновані технології видалися їм малоефективними. Ми уважно проаналізували їхні анкетні відповіді і з'ясували таке. На наш погляд, одна жінка-магістрант зазначила неефективність технологій через неуважність. Ми дійшли цього висновку з огляду на те, що вона зазначила, що брала активну участь в аудиторних заняттях та займалася самопідготовкою між заняттями, зможе скористатись усіма техніками групової роботи 3 особовим складом та здатна визначити і зняти стресові напруження в усіх зонах тіла, які розглядались у спецкурсі. Крім того, вона висловила впевненість, що зможе самостійно застосовувати свої вміння у професійній діяльності і у своїх відгуках позитивно оцінила спецкурс та висловила потребу в конспектуванні його матеріалів.

Дещо менш оптимістично відповіли на питання про застосовування своїх умінь у професійній діяльності чоловіки-магістранти. Загалом, таких виявилося 6 осіб із 16. Ми звернули увагу на те, що троє $з$ них також зазначили, що вони не отримали необхідні первинні знання та уміння $i$ не зможуть самостійно застосовувати запропоновані технології у своїй професійній діяльності. Їхні відповіді ми проаналізували вище. Серед трьох інших один із магістрантів написав, що зможе використовувати більшість запропонованих технік групової роботи з особовим складом, а щодо технік зняття стресових станів 3 певних зон тіла зауважив, що зможе скористатися двома із трьох. Також він вважає, що отримав первинні знання та уміння, щоб самостійно застосовувати запропоновані технології, але потребує додаткових знань та умінь щзодо їх застосування. Також курсант визнав, що завдяки участі в спецкурсі “дізнався новий матеріал для себе”, однак має значну потребу в подальшому вдосконаленні фахової психологічної підготовки. 3 його побажань можна зробити висновок про те, що йому видалися не зовсім прийнятними власне тілесно зорієнтовані технології і способи їх застосування.

Інший курсант зазначив, що може скористатися всіма запропонованими техніками групової роботи та більшістю технологій зняття стресових станів і вважає, що зможе їх самостійно застосовувати, хоч і потребує додаткових знань та умінь щзодо застосування запропонованих технологій. 3 огляду на вищезазначене виникає думка, що цей курсант був не дуже уважним, відповідаючи на це питання, і помилково обрав таку оцінку.

Останній курсант-магістрант, на наш погляд, проявив певну легковажність i недостатню відповідальність щодо участі в заняттях і під час заповнення анкети. Хоч він i зазначив, що брав активну участь у заняттях, проте визнав, що зможе скористатися лише однією технікою групової роботи і однією технологією зняття стресового стану. Також він вважає, що, хоч і не отримав первинних знань та умінь, проте зможе самостійно застосовувати запропоновані технології у своїй професійній діяльності. Що ж до побажань щодо вдосконалення спецкурсу, він написав: "Усе в нормі".

Отже, аналіз індивідуальних анкет курсантів-магістрантів, які оцінили запропоновані в спецкурсі технології як малоефективні для себе, дає підстави зробити такий висновок. У трьох курсантів таке ставлення зумовлене тим, що вони не засвоїли належним чином матеріал спецкурсу. Одна магістрантка і один магістрант, за нашим припущенням, зазначили цю позицію анкети помилково, а ще один магістрант проявив легковажне ставлення до заповнення анкети. Також один із шести магістрантів потребує індивідуального підходу та психокорекційної допомоги в опрацюванні психологічних захистів та подоланні спротиву щодо застосування тілесно зорієнтованих технологій.

На відкрите питання щодо потреби у вдосконаленні своєї фахової психологічної підготовки зацікавленість у такому вдосконаленні виявили 33\% магістрантів і 77\% першокурсників (від чисельності їхніх груп), із них - 9 жінок, у тому числі 3 магістрантки і 6 першокурсниць; із числа чоловіків - 13 осіб, у тому числі 5 магістрантів і 8 першокурсників. На питання “у чому саме?” учасники спецкурсу, серед іншого, зазначили: “вдосконалення теоретичних знань”, “правильно надавати допомогу особовому складу”, “краще розуміти технологію вправ, щоб застосовувати їх у потрібний момент", “поповнити свої знання i навички". 
Для визначення загальної оцінки корисності участі в заняттях спецкурсу в анкеті було запропоновано конкретизувати іï («Будь ласка, назвіть декілька позицій, чим була корисною для вас участь у спецкурсі»). Конкретні судження щодо цього питання висловили понад дві третини (71\%) учасників (30 із 42), серед них - 13 жінок, у тому числі 7 магістранток i 6 першокурсниць; 17 чоловіків, у тому числі 7 магістрантів і 10 першокурсників. У розрізі груп на це питання відповіли $58 \%$ магістрів і $89 \%$ першокурсників. У своїх відповідях, серед іншого, учасники зазначили: "відкрила для себе нові технології самодопомоги”, “отримала додаткові знання та досвід”, “дізналася про техніки допомоги особовому складу”, “курс допоміг і навчив знімати стрес", "можу краще оцінювати посттравматичні стресові стани", “користь від практичних групових занять", "користь від постійної роботи, багато інформації, можна застосовувати в роботі з особовим складом", "навчився виконувати багато вправ $\mathrm{i}$ оволодів засобами".

Що ж до пропозиції сформулювати декілька побажань щодо вдосконалення спецкурсу, то відгукнувся кожен другий респондент (22 особи із 42). За групами: $33 \%$ магістрантів і 78\% першокурсників; із них - 9 жінок (3 магістрантки і 6 першокурсниць) i 13 чоловіків (5 магістрантів і 8 першокурсників). Основними побажаннями учасників спецкурсу були такі: “потрібно було б законспектувати основну інформацію”, “є потреба в подальших нових методиках та цікавих групових заняттях", “проводити більше занять, удосконалювати методики”, “курс був доречним і цікавим”, “більше практики, більше нових методик”, “більше способів для проведення детального розбору і для вирішення проблем”, "рекомендувати частіше виконувати вправи у вільний час".

Висновки та перспективи подальших досліджень. На основі порівняльного аналізу самооцінювання курсантами-психологами першого курсу навчання i магістрантами досягнутих умінь та засвоєння ними первинних навичок само- i взаємодопомоги в опануванні стресових та посттравматичних стресових станів, а також їхньої здатності надавати відповідну психологічну допомогу особовому складу визначено основні чинники результативності їх навчально-методичного супроводу. Основними серед них $\epsilon$ активність, мотивація, спрямованість та командна згуртованість курсантів.

Оскільки з'ясувалось, що рівень засвоєння технологій у першокурсників вищий $(100 \%)$, ніж у магістрантів (75\%), доцільним видається зосередити увагу на вдосконаленні програми навчального курсу, іiі спеціалізації для фахових потреб магістрів, зокрема передбачити можливість їх індивідуального консультування. Важливим $є$ врахування побажань і першокурсників, і магістрантів щодо урізноманітнення практичних вправ, більш детального їх пояснення і практичного опрацювання. Зворотний зв'язок, отриманий від учасників курсу, також засвідчив необхідність урахування гендерних аспектів організації і проведення практичних занять. Загалом, більшість учасників (60\%) засвідчили потребу в отриманні додаткових знань та умінь щодо застосування запропонованих технологій, удосконалення своєї фахової психологічної підготовки. Тому в навчальній програмі курсу по його закінченні доцільно передбачити відповідний огляд джерел, де учасники курсу змогли б знайти потрібну для них інформацію

Насамкінець зазначимо, що проведений аналіз базувався на самооцінюванні учасниками набутих ними знань та умінь у процесі навчання. Тому перспективи подальшого дослідження вбачаємо у вивченні ефективності застосування набутих навичок учасниками навчального курсу після іх стажування у військах та в їхній практичній роботі з особовим складом за місцем проходження служби. Такі дослідження допоможуть суттєво вдосконалити пропонований нами навчально-методичний курс.

\section{Список використаних джерел}

Балашова, С. П., Васильєв, С. П., \& Дубровинський, Г. Р. (2013). Практичний курс військової nсихології: навчальний посібник. Частина 2. Київ.: Київський національний університет імені Тараса Шевченка. 
Волкова, Н. С. (2016). Психологическое сопровождение военнослужащих при исполнении воинской обязанности в Российской Федерации. Научное обозрение. Медицинские науки, 3, 27-31.

Кокун, О. М., Агаєв, Н. А., Пішко, І. О., Лозінська, Н. С., \& Остапчук, В. В. (2017). Психологічна робота з військовослужбовиями-учасниками АТО на етапі відновлення. Київ : НДЦ ГП 3СУ.

Лазоренко, Б., \& Дубровинський, Г. (2019). Підготовка військового психолога до використання технологій оптимізації психологічного стану особового складу щодо виконання завдань в особливих умовах. В Філософсько-соиіологічні та психолого-педагогічні проблеми підготовки особистості до виконання завдань в особливих умовах: зб. матеріалів, доповідей Всеукр. наук.-практ. конф. (с. 161-164). Київ : НУОУ.

Осьодло, В. І., \& Зубовський, Д. С. (2017). Посттравматичне зростання особистості учасників бойових дій: сучасний стан та перспективи. Украӥнський психологічний журнал, 1, 63-79.

Титаренко, Т. М., Климчук, В. О., Лазоренко, Б. П., Ларіна, Т. О., Дворник, М. С., Мирончак, К. В., ... \& Савінов, В. В. (2019). Соиіально-психологічні технології відновлення особистості після травматичних подій. Кропивницький: Імекс-ЛТД.

Gaillard, A. W. K., Soeters, J. M. L. M., \& Delahaij, R. (2006). Stress Training and the New Military Environment. Взято 3 https://bit.ly/2GWeW1F.

\section{References}

Balashova, S. P., Vasylyev, S. P., \& Dubrovynskyy, H. R. (2013). Praktychnyi kurs viiskovoi psykholohii: navchalnyi posibnyk. Chastyna 2 [Practical course of military psychology: textbook. Part 2]. Kyiv: Kyivskyi natsionalnyi universytet imeni Tarasa Shevchenka. (in Ukrainian)

Gaillard, A. W. K., Soeters, J. M. L. M., \& Delahaij, R. (2006). Stress Training and the New Military Environment. Retrieved from https://bit.ly/2GWeW1F. (in English)

Kokun, O. M., Ahayev, N. A., Pishko, I. O., Lozinska, N. S., \& Ostapchuk, V. V. (2017). Psykholohichna robota $z$ viiskovosluzhbovtsiamy-uchasnykamy ATO na etapi vidnovlennia [Psychological work with servicemen-participants of anti-terrorist operation at the stage of recovery]. Kyiv : NDTS HP ZSU. (in Ukrainian)

Lazorenko, B., \& Dubrovynskyi, H. (2019). Pidhotovka viiskovoho psykholoha do vykorystannia tekhnolohii optymizatsii psykholohichnoho stanu osobovoho skladu shchodo vykonannia zavdan $\mathrm{v}$ osoblyvykh umovakh [Training of a military psychologist to use technologies to optimize the psychological state of personnel to perform tasks in special conditions]. In Filosofsko-sotsiolohichni ta psykholohopedahohichni problemy pidhotovky osobystosti do vykonannya zavdan $v$ osoblyvykh umovakh: zbirnyk materialiv dopovidei Vseukrainskoi naukovo-praktychnoi konferentsii (pp. 161-164). Kyiv: NUOU. (in Ukrainian)

Osiodlo, V. I., \& Zubovskyy, D. S. (2017). Posttravmatychne zrostannia osobystosti uchasnykiv boiovykh dii: suchasnyy stan ta perspektyvy [Post-traumatic growth of the personality of combatants: current status and prospects]. Ukrainskyi psykholohichnyi zhurnal, 1, 63-79. (in Ukrainian)

Volkova, N. S. (2016). Psikhologicheskoye soprovozhdeniye voyennosluzhashchikh pri ispolnenii voinskoy obyazannosti v Rossiyskoy Federatsii [Psychological support of servicemen on military duty in the Russian Federation]. Nauchnoye obozreniye. Meditsinskiye nauki, 3, 27-31. (in Russian)

Tytarenko, T. M., Klymchuk, V. O., Lazorenko, B. P., Larina, T. O., Dvornyk, M. S., Myronchak, K. V., ... \& Savinov, V. V. (2019). Sotsialno-psykholohichni tekhnolohii vidnovlennia osobystosti pislia travmatychnykh podii [Socio-psychological technologies of personality recovery after traumatic events]. Kropyvnytskyi: Imeks-LTD. (in Ukrainian) 